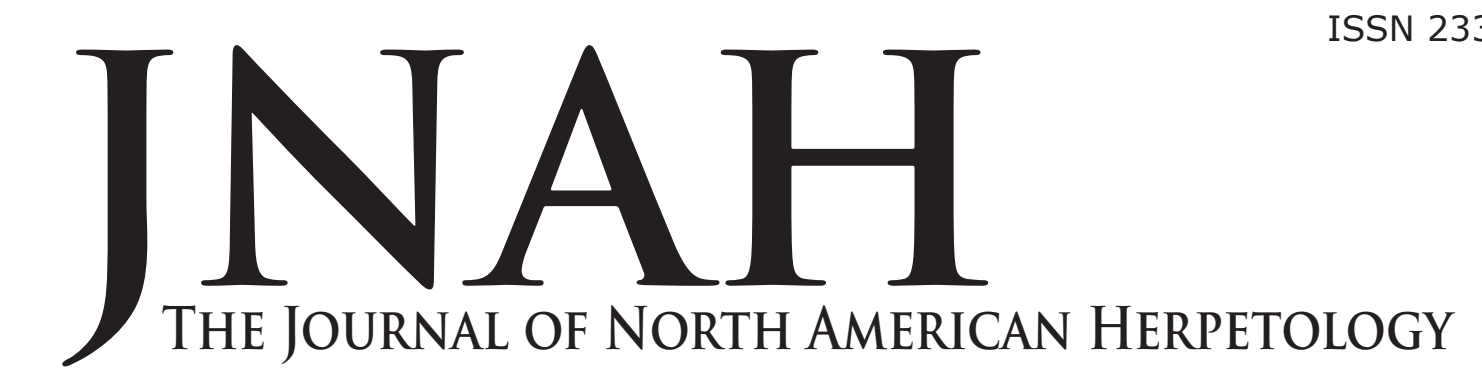

\begin{abstract}
Volume 2017(1): 19-27
29 March 2017

jnah.cnah.org

\section{SEASONAL INCIDENCE OF CAPTURE AND REPRODUCTION OF FIVE FOSSORIAL SNAKE SPECIES IN WEST VIRGINIA}

\author{
WALTER E. MESHAKA, JR. ${ }^{1}$, THOMAS K. PAULEY ${ }^{2}$, \\ DANIELLE F. WRIGHT'1 , AND KELLI-MARIE HERRICK²
}

${ }^{1}$ Section of Zoology and Botany, 300 North Street, Harrisburg, Pennsylvania 17120, USA [author contact: wmeshaka@ pa.gov]

${ }^{2}$ Department of Biological Sciences, Marshall University, One John Marshall Drive, Huntington, West Virginia 25755 USA

ABSTRACT - Museum specimens of five species of fossorial snakes collected in West Virginia during 1930-2000 were examined to determine monthly incidence of capture, adult body sizes, reproductive cycle, and clutch characteristics. Captures occurred over the shortest time in the year in the Eastern Earthsnake (Virginia valeriae valeriae) and Northern Red-bellied Snake (Storeria occipitomaculata occipitomaculata) and were longest in the Northern Brownsnake (S. dekayi dekayi). Male gonadal cycle conformed to the temperate pattern, whereas that of females tended towards a tropical pattern. Incidence of females nearing oviposition or parturition was highest during June-July for all species, and length of their reproductive seasons were generally in keeping with those of northerly populations of the respective species. Mean clutch sizes were largest in the Northern Brownsnake (mean $=20.5$ ) and smallest in the single oviparous snake, the Eastern Wormsnake (mean $=2.8$ ). Adult body sizes were similar to respective populations elsewhere within their ranges. The Mountain Earth Snake ( $V$. pulchra) was the least represented species in this study. A meaningful degree of predictability existed in the life history traits examined in our study as they related to geographic trends of this Allegheny snake assemblage.

\section{INTRODUCTION}

Twenty-two species of snakes are native to West Virginia (Green and Pauley, 1987). Five are smallbodied, predators of invertebrates, and fossorial in habits (Green and Pauley, 1987). Three of these, the Eastern Wormsnake, Carphophis amoenus amoenus (Say, 1825), Northern Brownsnake, Storeria dekayi dekayi (Holbrook, 1836), and Northern Red-bellied Snake, Storeria occipitomaculata occipitomaculata (Storer, 1839), are either widespread in or occur in approximately one half of West Virginia, and two species, the Mountain Earthsnake, V. pulchra (Richmond, 1954) and the Eastern Earthsnake, Virginia valeriae valeriae Baird and Girard, 1853, are restricted to the northeastern corner of the state (Green and Pauley, 1987; Powell et al., 2016). Basic life history data are lacking for all of them. Access to West Virginia specimens of these five species from the holdings of the Carnegie Museum of Natural History and the herpetological collection of Marshall University provided us with the opportunity to examine certain life history traits. We were especially interested in understanding their responses in relation to findings in northern and southern latitudes.

MATERIALS AND METHODS

Specimens of the five species of snakes were examined from the holdings of Marshall University Museum of
Natural History and the Carnegie Museum of Natural History. Body length was measured in $\mathrm{cm}$ as snout-vent length (SVL). Sex was determined by examination of the gonads. Enlarged testes indicated sexual maturity in males. The length and width in $\mathrm{mm}$ at the center of the right testis was each expressed as a percentage of the SVL to provide a monthly distribution of testis size. Methods by Trauth et al. (1994) served as guidelines for size ranges associated with categories of ovarian follicles and oviductal eggs and embryos. Follicles $<2 \mathrm{~mm}$ were deemed immature. Vitellogenic ovarian follicles were generally $\geq 3 \mathrm{~mm}$.

The largest ovarian follicle among those $\geq 2.0 \mathrm{~mm}$ was used to provide a measure of monthly follicular growth. The largest oviductal eggs or embryos were measured for a monthly estimate of respective growth rates. Clutch size was estimated by counts of enlarged follicles, oviductal eggs or counts of young. Mean values were followed by \pm 1 standard deviation. F-tests were performed to test for statistical differences in variances around the means. Two-tailed t-tests were performed to test for statistical differences between means. All statistical analyses were performed using Microsoft Excel version 2010.

RESULTS
Species Accounts
Carphophis amoenus amoenus (Say, 1825) - One




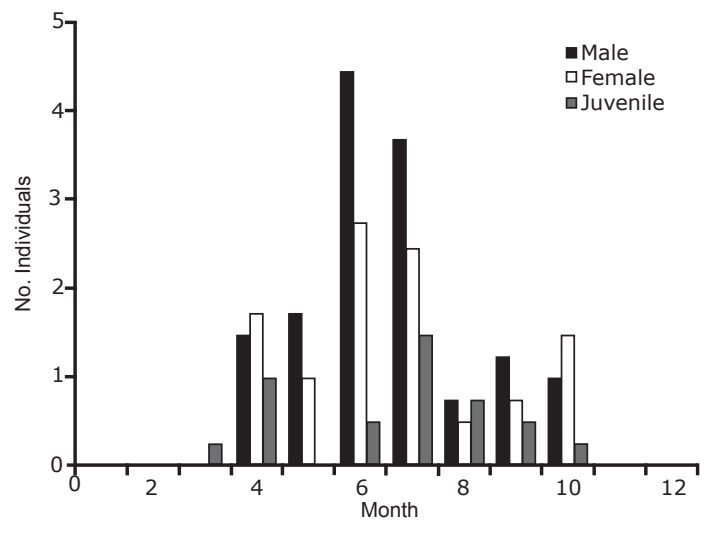

Figure 1. Monthly incidence of captures of 58 male, 43 female, and 19 juvenile Eastern Wormsnakes (Carphophis amoenus amoenus) from West Virginia.

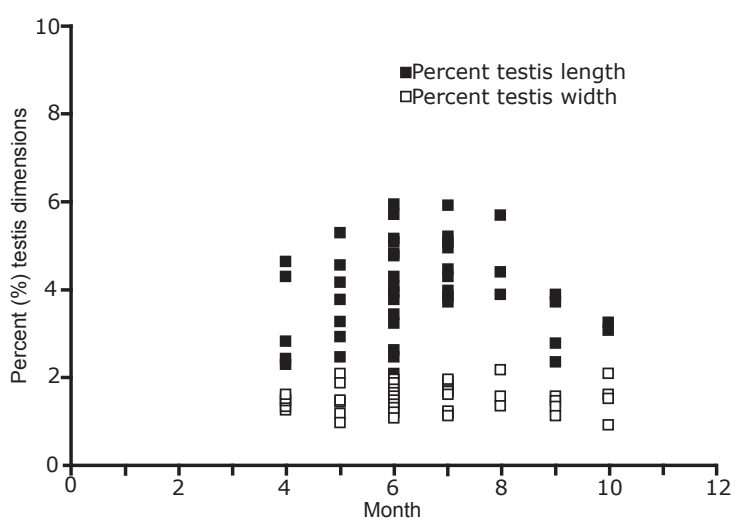

Figure 2. Monthly distribution of testis size as a percentage of male snout-vent length (SVL) of 56 Eastern Wormsnakes (Carphophis amoenus amoenus) from West Virginia.

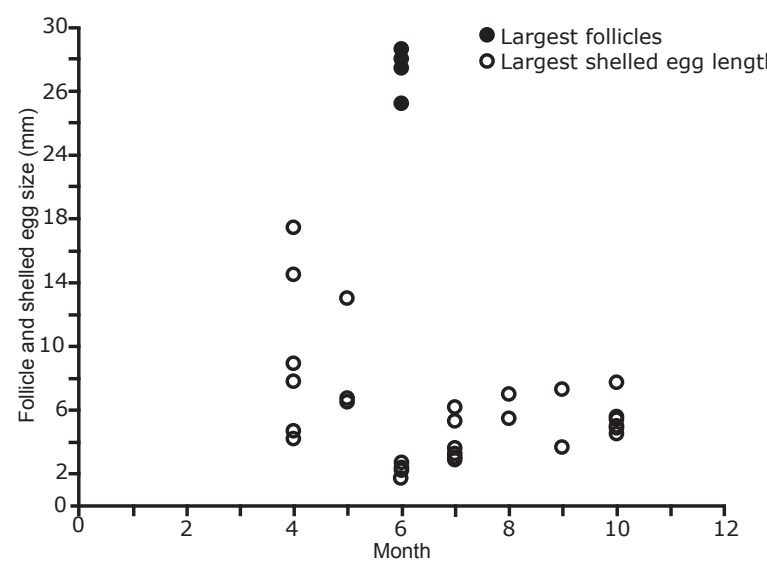

Figure 3. Monthly distribution of follicle and ovum size in 37 Eastern Wormsnakes (Carphophis amoenus amoenus) from West Virginia.

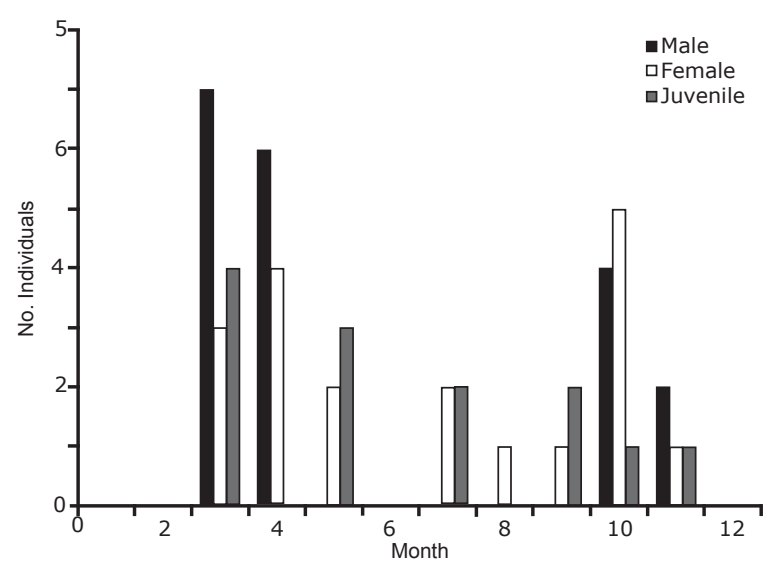

Figure 5. Monthly incidence of captures of 19 male, 19 female, and 13 juvenile Northern Brownsnakes (Storeria dekayi dekayi) from West Virginia.

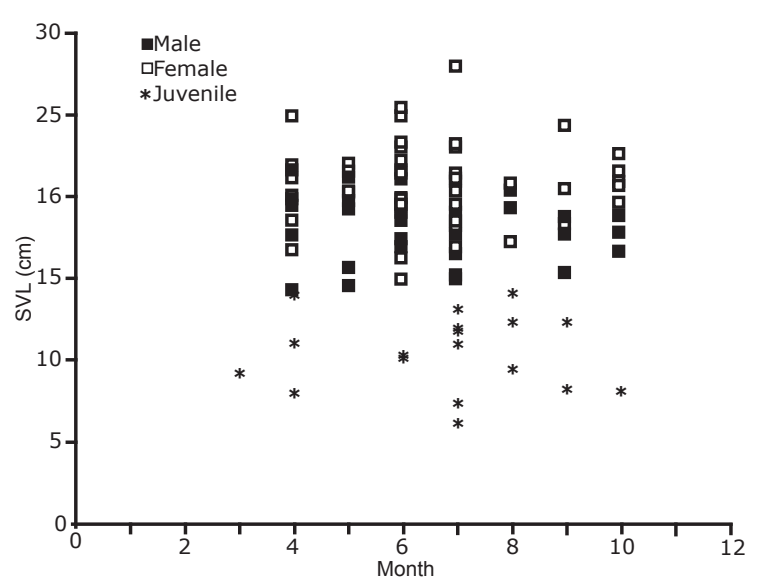

Figure 4. Monthly distribution of snout-vent lengths (SVL) of 58 male, 43 female, and 19 juvenile Eastern Wormsnakes (Carphophis amoenus amoenus) from West Virginia.

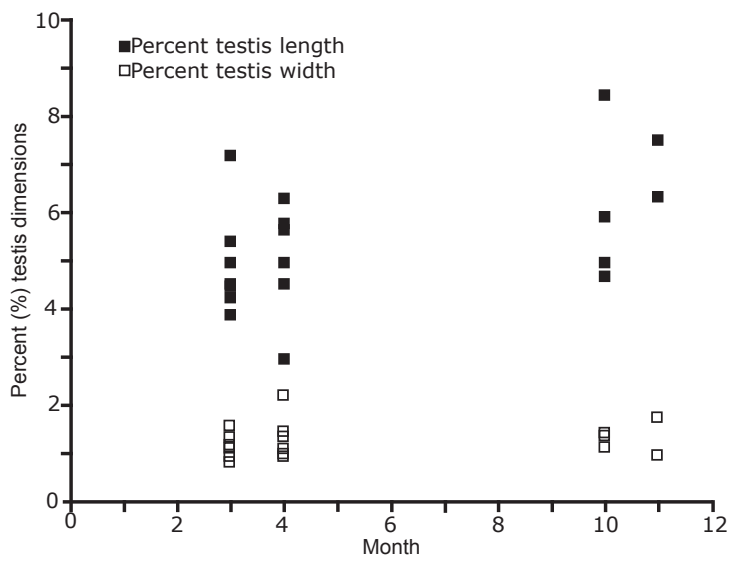

Figure 6. Monthly distribution of testis size as a percentage of male snout-vent length (SVL) of 19 Northern Brownsnakes (Storeria dekayi dekayi) from West Virginia. 


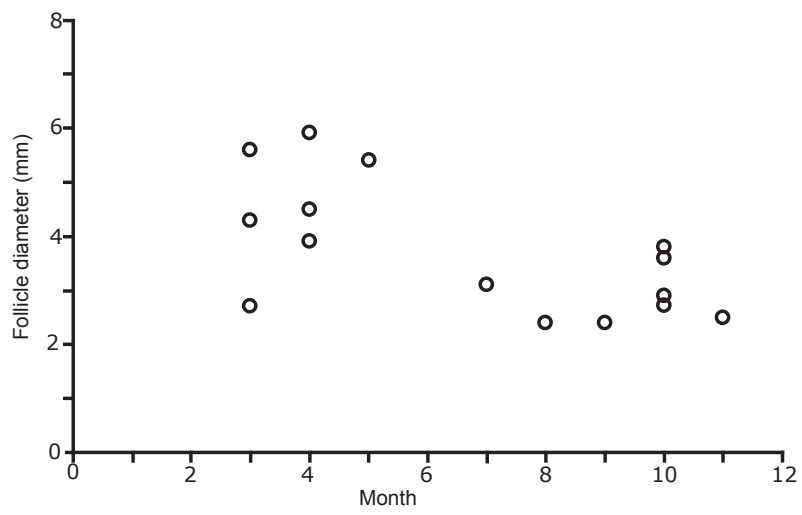

Figure 7. Monthly distribution of follicle size in 17 Northern Brownsnakes (Storeria dekayi dekayi) from West Virginia.

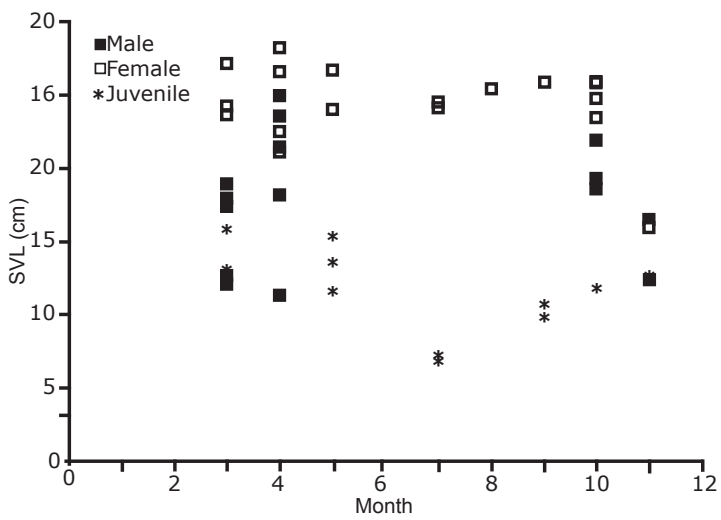

Figure 9. Monthly distribution of snout-vent lengths (SVL) of 19 male, 19 female, and 13 juvenile Northern Brownsnakes (Storeria dekayi dekayi) from West Virginia.

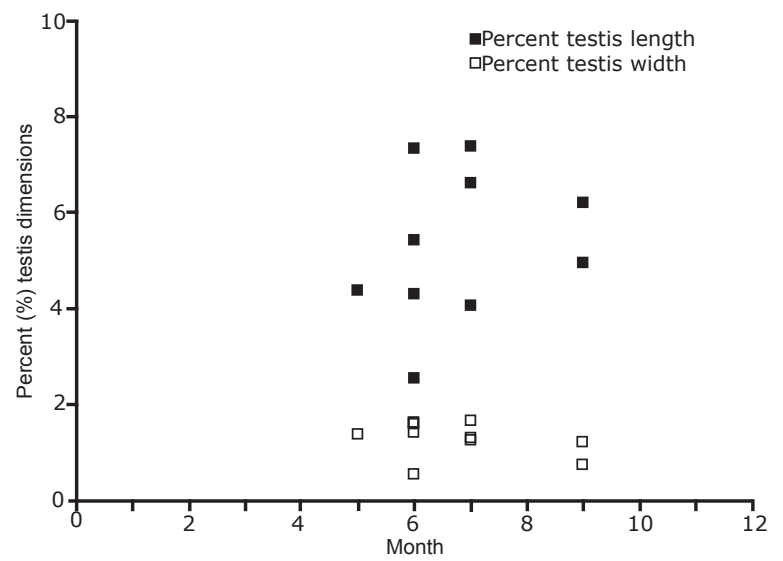

Figure 11. Monthly distribution of testis size as a percentage of male snout-vent length (SVL) of 11 Northern Red-bellied Snakes (Storeria occipitomaculata occipitomaculata) from West Virginia.

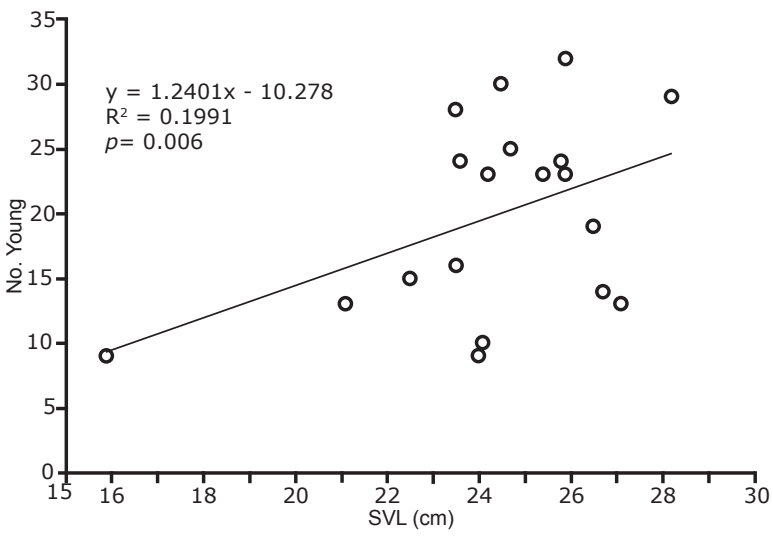

Figure 8. Relationship between clutch size and female snoutvent length (SVL) of 17 Northern Brownsnakes (Storeria dekayi dekayi) from West Virginia.

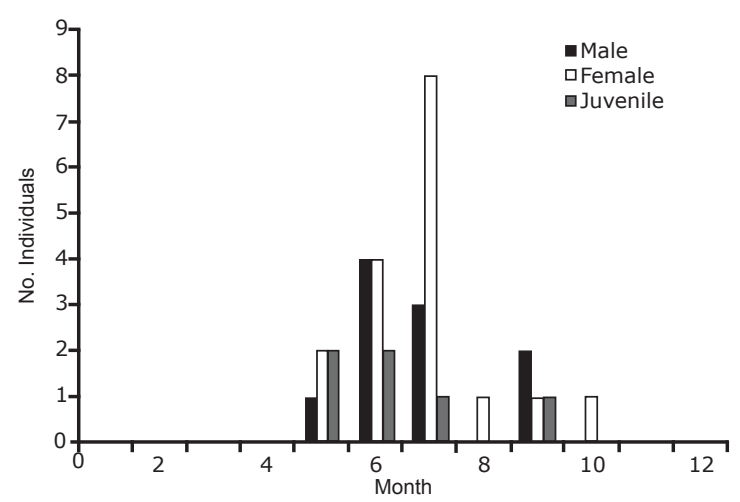

Figure 10. Monthly incidence of captures of 11 male, 17 female, and five juvenile Northern Red-bellied Snakes (Storeria occipitomaculata occipitomaculata) from West Virginia.

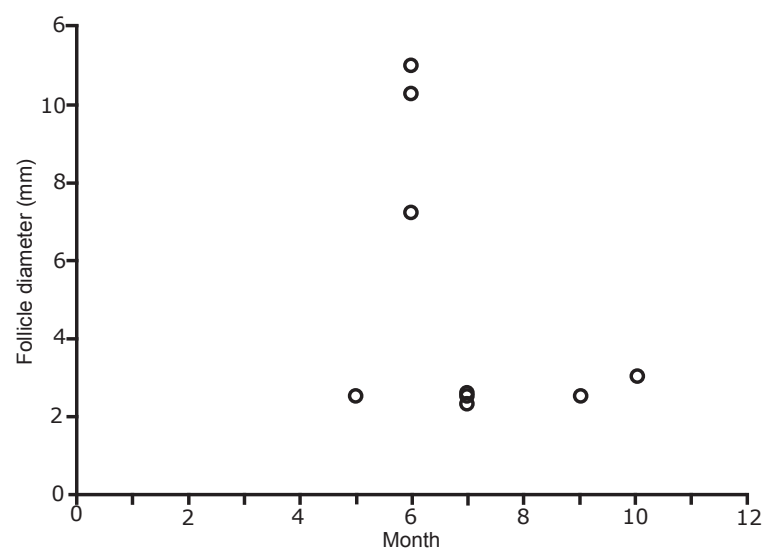

Figure 12. Monthly distribution of largest follicle size in nine Northern Red-bellied Snakes (Storeria occipitomaculata occipitomaculata) from West Virginia. 
Table 1. Adult body sizes in cm SVL (mean followed by range) and clutch sizes of the Common Wormsnake (Carphophis amoenus) from various locations in the United States.

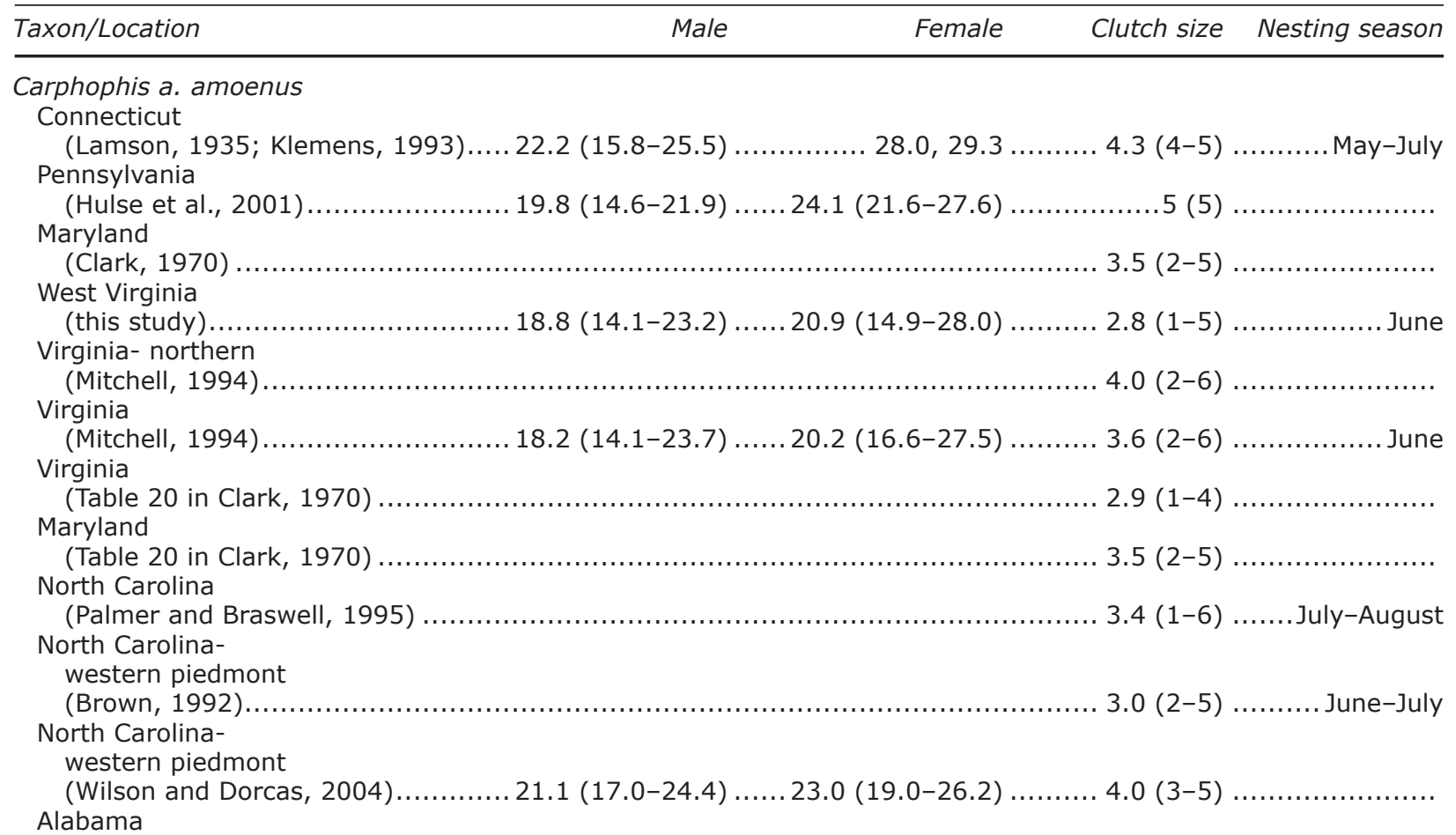

(Mount, 1975).

Usually $5(2-8)$

\section{Carphophis a. helenae \\ Indiana}

(Minton, 2001)

$22.1(17.0-25.2) \ldots . .26 .6(21.4-31.9)$

$(7-14)$ .. June-July

Illinois

(Table 20 in Clark, 1970)

Kentucky

(Table 20 in Clark, 1970)

$3.7(2-6)$

$4.0(2-6)$

Carphophis a. amoenus X C. a. helenae

Kentucky

(Barbour, 1960)

$2.6(2-5)$ June

hundred and twenty specimens of the Eastern Wormsnake were examined from collections made during 1931-2000 in West Virginia.

Capture incidence: The Eastern Wormsnakes were captured during March-October, with most snakes collected during June-July (Figure 1). A unimodal pattern to monthly captures was evident among the adults, whereby captures of both sexes were greatest during June-July. Male captures outnumbered those of females (Figure 1). Too few juveniles were captured to determine the presence of amplitudes in their capture incidence; however, most juveniles were captured in July (Figure 1).

Reproduction: Monthly distribution of testis size among Eastern Wormsnakes indicated a rapid increase in testis length, having peaked during June-July, followed by a rapid decrease in length thereafter (Figure 2). Monthly distribution in testis width indicated no definite seasonal pattern (Figure 2). Follicular growth was rapid in the spring. A single clutch of eggs was laid in June, followed by a gradual increase of the next size cohort of follicle size to up to $8 \mathrm{~mm}$ by October to form the ensuing year's clutch (Figure 3 ). Clutch size as estimated from counts of vitellogenic ovarian follicles $(\geq 3.0 \mathrm{~mm}$ ) averaged 3.3 eggs ( $\pm 1.0 ;$ range $=2-5 ; n=8)$. Clutch size estimated from counts of shelled eggs averaged 2.2 eggs $( \pm 0.8$; range $=1-3 ; n=5)$. No significant difference $(p>0.05)$ existed in variance ( $F$ test) or mean (t-test) of these two clutch estimates. Combining data from both counts yielded a mean clutch size estimate of 2.8 ( \pm 1.1 ; range $=1-5 ; n=13)$. Mean shelled egg length and width was available for eight eggs: Mean egg length $=25.8 \pm 2.3$ $\mathrm{mm}$; range $=22.0-28.6$, mean egg width $=6.6 \pm 0.9$ $\mathrm{mm}$; range $=5.4-8.3$.

Body sizes and growth to maturity: The smallest individuals were collected in July (Figure 4). Based upon presumed monthly size-class groupings, monthly body size distribution of Eastern Wormsnakes indicated a minimum age at sexual maturity of approximately 21 months at a body size of $14.1 \mathrm{~cm}$ SVL in males and 14.9 $\mathrm{cm}$ SVL in females (Figure 4). Among adults, mean body size of males (mean $=18.6 \pm 2.1 \mathrm{~cm}$; range $=14.1-$ $23.2 ; n=58)$ was significantly different $(t=-4.7983$; $d f$ $=99 ; \mathrm{p}<0.0000)$ from that of females (mean $=20.9 \pm$ $2.6 \mathrm{~cm}$; range $=14.9-28.0 ; \mathrm{n}=43$ ).

Storeria dekayi dekayi (Holbrook, 1836) - Fifty-one 
Table 2. Adult body sizes in cm SVL (mean followed by range) and clutch sizes of the Mountain Earthsnake (Virginia pulchra) and Smooth Earthsnake (Virginia valeriae) from various locations in the United States.

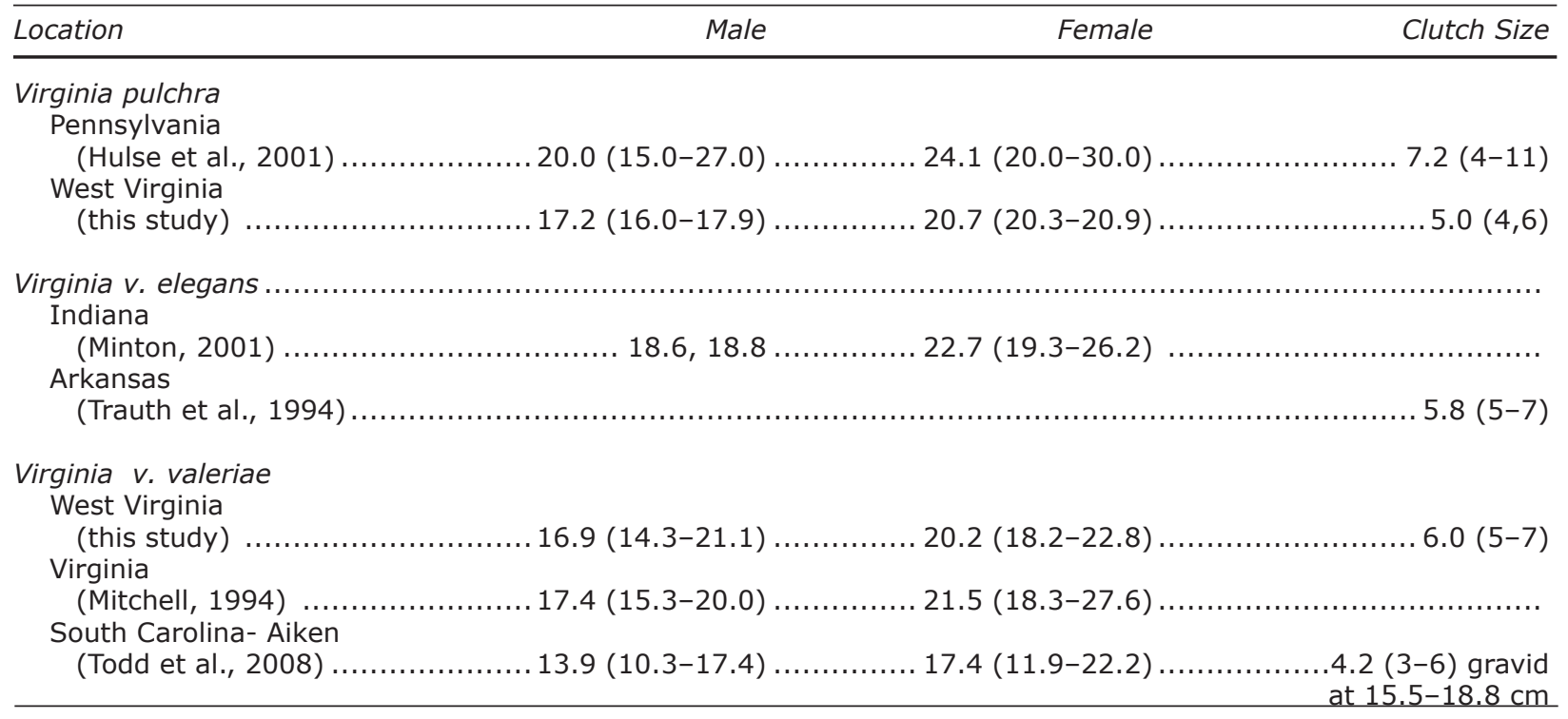

specimens of the Northern Brownsnake were examined from collections made during 1930-1941 in West Virginia.

Capture incidence: The Northern Brownsnake was captured during March-November, with most snakes collected in March (Figure 5). A spring and late fall bimodal pulse in capture incidence was apparent in both sexes, with the larger pulse evident in spring (Figure 5). Juveniles were detected during March-November with captures decreasing rapidly after March (Figure 5).

Reproduction: Monthly distribution of testis size among Northern Brownsnakes was limited to spring and fall collections, at which times they appeared to be large, especially in the fall (Figure 6). Follicular growth was evident in spring (Figure 7). Oviductal embryos were found in May and July, after which time follicle size ranged 2.4-3.8 $\mathrm{mm}$ (Figure 7).

Mean clutch size as estimated from counts of ovarian follicles $(2.4-2.9 \mathrm{~mm}$ ) measured 22.4 ( \pm 7.7 ; range = $9-32 ; n=7)$ and did not differ significantly (t-test; $p$ $>0.05$ ) from mean clutch size (mean $=20.3 \pm 6.5$; range $=13-30 ; n=10$ ) as estimated from counts of vitellogenic ovarian follicles (3.1-5.9 mm). A $24.0 \mathrm{~cm}$ SVL female captured on 5 May 1938 contained nine oviductal embryos, and a $24.1 \mathrm{~cm}$ SVL female captured on 4 July 1938 contained 10 near-term conceptuses. Combining all clutch size data provided a grand mean of $20.0 \pm 7.4 ;$ range $=9-32 ; n=19)$. Mean body size of females from the combined sample measured $24.4 \pm 2.7$ $\mathrm{cm}$ SVL; range $=15.9-28.2 ; \mathrm{n}=17)$. The relationship between clutch size based on combined measures of estimation and female body size was marginally not significant (Figure 8).

Body sizes and growth to maturity- Monthly distribution of body sizes indicated rapid growth to sexual maturity in males $(11.3 \mathrm{~cm} \mathrm{SVL})$ and females $(15.9 \mathrm{~cm} \mathrm{SVL})$ : Late fall, approximately four months after birth in males, and the following summer in females (Figure 9). Mean body size of males $($ mean $=18.0 \pm 4.3 \mathrm{~cm}$; range $=11.3-$ $25.0 ; n=19)$ was significantly different $(F=2.4078, p$ $=0.04 ; \mathrm{t}=-5.2168 ; \mathrm{df}=291 ; \mathrm{p}<0.0000)$ than that of females $($ mean $=24.4 \pm 2.7 \mathrm{~cm}$; range $=15.9-28.2$; $\mathrm{n}=19$ ).

Storeria occipitomaculata occipitomaculata (Storer,
1839) - Thirty-three specimens of the Northern Redbellied Snake were examined from collections made during 1931-1987 in West Virginia.

Capture incidence: The Northern Red-bellied Snake was captured during May-October, with most snakes collected during June-July (Figure 10). A unimodal pattern to monthly capture incidence was evident in adults, having peaked in June among males and July among females (Figure 10). Among females, captures were more likely at that time as they sought out sites conducive to development of young in advance of parturition. Too few juveniles were captured to determine the presence of amplitudes in their capture incidence; however, juveniles were captured during May-September (Figure 10).

Reproduction: Monthly distribution of testis size among Northern Red-bellied Snakes revealed a peak in both length and width during June-July (Figure 11). From a small sample size of nine females, gravid individuals, as determined by follicle size, were detected in June (Figure 12). Thereafter, largest follicle sizes were of a size denoting the end of the gravid condition and commencement of vitellogenesis (Figure 12). Developing

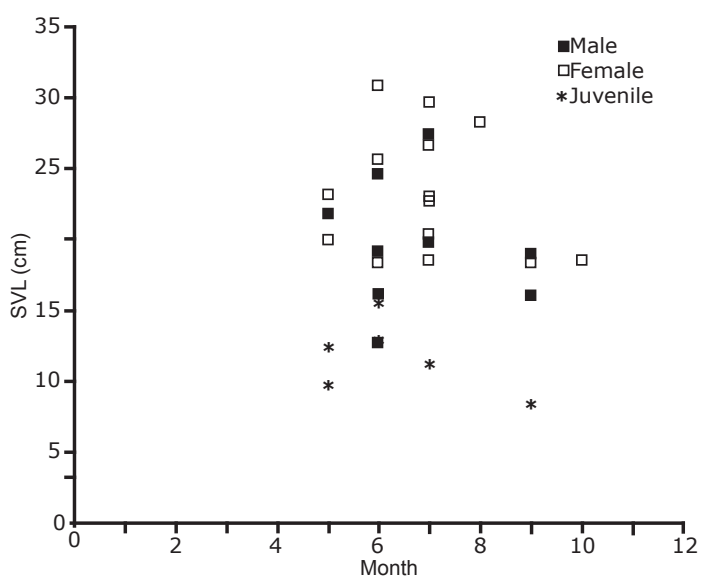

Figure 13. Monthly distribution of snout-vent lengths (SVL) of 10 male, 17 female, and six juvenile Northern Red-bellied Snakes (Storeria occipitomaculata occipitomaculata) from West Virginia. 
conceptuses in the oviducts of eight females were detected in May $(n=1)$, June $(n=1)$, July $(n=5)$, and August $(n=1)$. Clutch size as estimated from counts of pre-vitellogenic ovarian follicles $(2.3-2.6 \mathrm{~mm})$ averaged 13.2 young $( \pm 1.3 ;$ range $=12-15 ; n=5)$. Clutch size estimated from counts of vitellogenic ovarian follicles $(3.0-11.0 \mathrm{~mm})$ averaged $12.0( \pm 6.7 ;$ range $=6-21 ; \mathrm{n}$ $=4)$. Variance between the means of these two samples were significantly different $(F=26.2745, p=0.004)$; however, the means did not differ significantly from one another (t-test, $\mathrm{p}<0.05$ ). Combining data from both counts yielded a mean clutch size estimate of 12.7 ( \pm 4.2 ; range $=6-21 ; n=9)$, which in turn did not differ significantly in either variance or mean (t-test, $p>$ 0.05 ) from those of clutch size estimated from counts of oviductal embryos $($ mean $=11.6 \pm 3.59$; range $=7-17$; $\mathrm{n}=8$ ). A $28.2 \mathrm{~mm}$ SVL female collected on 5 August 1939 had 17 near term young, nine of which were male. Mean body size of the young did not differ significantly $(p>0.05)$ between the sexes with respect to variance ( $F$ test) or mean (t-test). For all young, mean body size measured $5.1 \pm 0.2 \mathrm{~mm} \mathrm{SVL}$; range $=4.8-5.5 ; \mathrm{n}=17$.

Body sizes and growth to maturity: Mean body size of males (mean $=19.6 \pm 4.2 \mathrm{~cm}$; range $=12.7-27.4$; $\mathrm{n}=10)$ was significantly different $(\mathrm{t}=-2.1683, \mathrm{df}=$ $25 ; p<0.04$ ) than that of females (mean $=23.4 \pm 4.4$ $\mathrm{cm} ;$ range $=18.3-30.8 ; \mathrm{n}=17$ ). Individuals somewhat smaller than the $8.4 \mathrm{~cm}$ SVL young-of-the-year collected in September (Figure 13) would have been born in midsummer. Sexual maturity would presumably be reached by males at $12-13 \mathrm{~cm}$ SVL by the following summer and by females at $18.3 \mathrm{~cm} \mathrm{SVL}$ at approximately two years of age (Figure 13).

Virginia pulchra (Richmond, 1954) - Seven specimens of the Mountain Earthsnake were examined from collections made during 1964-1983 in West Virginia.

Capture incidence: The Mountain Earthsnake was collected during June-September. A male and two females were collected in June, one male each in July and September, and a single female and juvenile in September.

Reproduction: Two females were collected from which clutch size could be estimated using oviductal compliments. A $20.9 \mathrm{~mm}$ SVL female collected on 16 June 1983 contained six developing young. A 20.3

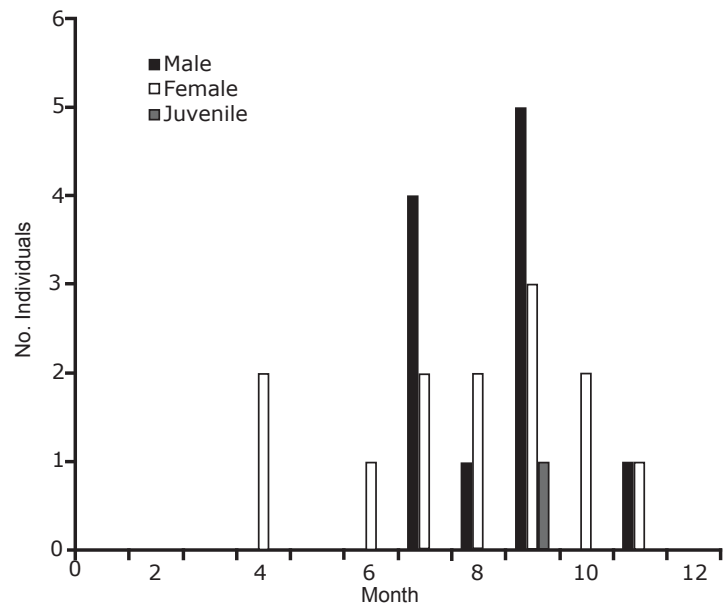

Figure 14. Monthly incidence of captures of 11 male, 13 female, and one juvenile Eastern Earthsnakes (Virginia valeriae valeriae) from West Virginia. mm SVL female collected on 20 June 1969 contained four vitellogenic ovarian follicles, the largest of which measured $7.9 \mathrm{~mm}$.

Body sizes and growth to maturity- Adult body sizes were available for three males (mean $=17.2 \pm 1.0 \mathrm{~cm}$; range $=16.0-17.9)$ and three females $($ mean $=20.7 \pm$ $0.4 \mathrm{~cm}$; range $=20.3-20.9$ ) .

Virginia valeriae valeriae Baird and Girard, 1853 Twenty-five specimens of the Eastern Earthsnake were examined from collections made during 1935-1999 in West Virginia.

Capture incidence: The Eastern Earthsnake was collected during April-November, with most snakes collected in September (Figure 14). Females were captured over more months (April-November) than males (July-November), and only one juvenile, captured in September, was present in this sample. In light of small sample sizes, assessment of seasonal amplitudes is tentative for adults (Figure 14).

Reproduction: Monthly distribution of testis size was restricted to a July-November collection (Figure 15). Lengths and widths of the testes appeared to have been largest by September (Figure 15). Clutch size estimated from counts of developing conceptuses averaged 6.0 young $( \pm 1.2$; range $=5-7$ ) from four females (mean $=20.2 \pm 1.9 \mathrm{~cm} \mathrm{SVL}$; range $=18.8-22.8$ ). Based upon the sizes of follicles at the end of the season and in April, follicular growth was rapid in the spring (Figure 16). Two of the clutches were near-term on 4 July 1938 . The two other clutches were obtained from collections on 11 August 1941.

Body sizes and growth to maturity: The smallest individual, a $9.6 \mathrm{~cm}$ SVL young-of-the-year collected in September (Figure 17) would have likely been born in July or August. The next size-class to be detected is among males the following year that are at or near the minimum body size at sexual maturity of $14.3 \mathrm{~cm} \mathrm{SVL}$ (Figure 17). The minimum body size of sexually mature females was $18.2 \mathrm{~cm} \mathrm{SVL}$, which seemed likely by spring the year after at an age of approximately 21 months. Mean body size of males (mean $=16.9 \pm 2.4 \mathrm{~cm}$; range $=14.3-21.1 ; \mathrm{n}=11)$ was significantly different $(\mathrm{F}=$ 2.8402, $\mathrm{p}=0.05 ; \mathrm{t}=-4.0509 ; \mathrm{df}=16 ; \mathrm{p}=0.0009)$ than that of females (mean $=20.2 \pm 1.4 \mathrm{~cm}$; range $=$ $18.2-22.8 ; n=13)$.

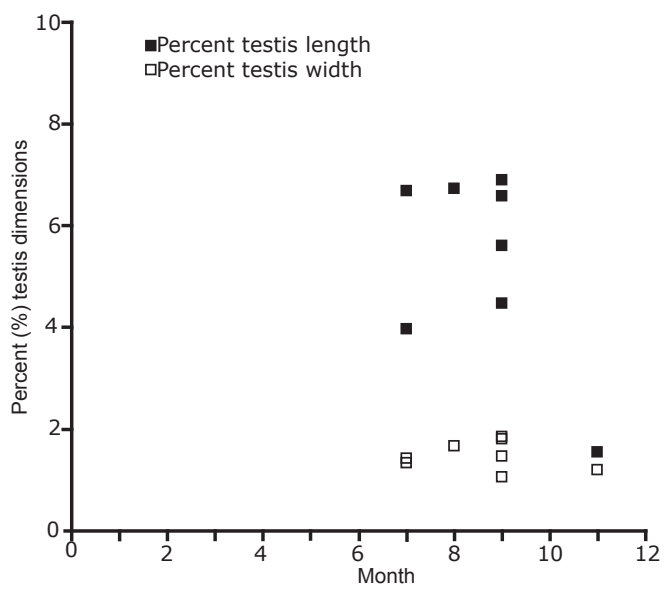

Figure 15. Monthly distribution of testis size as a percentage of male snout-vent length (SVL) of 11 Eastern Earthsnakes (Virginia valeriae valeriae) from West Virginia. 


\section{DISCUSSION}

Interspecific comparisons - West Virginia has 22 species of snakes (Green and Pauley, 1987). Among them, the five species examined in this study are both small-bodied and prey exclusively on invertebrates (Green and Pauley, 1987). Body-size dimorphism was evident in all species examined in this study. Adult body sizes of both sexes were similar among the species. Exclusive of the Mountain Earthsnake that was represented by a very small sample size, the Eastern Earthsnake and Northern Red-bellied Snake appeared to have had the shortest active seasons, whereas the longest active season was detected in the Northern Brownsnake, followed by that of the Eastern Wormsnake. Monthly patterns to capture incidence of all but the Northern Brownsnake were unimodal.

Male gonadal cycle of most species we examined conformed to those of other north temperate populations of colubrid snakes, whereby spermatogenesis occurs in the summer (Saint Girons, 1982). At this time, testes are largest in dimensions. Exceptionally, we are unsure of the pattern of spermatogenesis of the Northern Brownsnake. The absence of reproductive material during May-September precludes confirmation of the temperate pattern (Saint Girons, 1982) as compared to the tropical pattern, whereby testis dimensions would be smallest in the summer (Aldridge et al., 1995); however, no conclusions can be drawn until summer material is examined. On the other hand, females of the Eastern Wormsnake, Northern Brownsnake, and Northern Red-bellied Snake adhered to a tropical pattern to vitellogenesis (Aldridge et al., 1995) rather than the type II spring vitellogenesis pattern typical of north temperate colubrids (Aldridge, 1979; Aldridge et al., 2009). To that end, female Northern Brownsnakes of Pennsylvania were found to have entered hibernation with follicles measuring $3.4 \mathrm{~mm}$ (Hulse et al., 2001), indicating commencement of vitellogenesis prior to spring. Likewise, the tropical pattern in vitellogenesis was also evident in Northern Red-bellied Snakes of Pennsylvania (Meshaka and Klippel, 2011). A tropical pattern to vitellogenesis appeared to be the case with the Eastern Earthsnake; however, we remain uncertain until more data are available.

Parturition and egg laying seasons overlapped among the species with June and July being the most common months. Exceptionally, the parturition season of the Eastern Earthsnake may have extended later, possibly

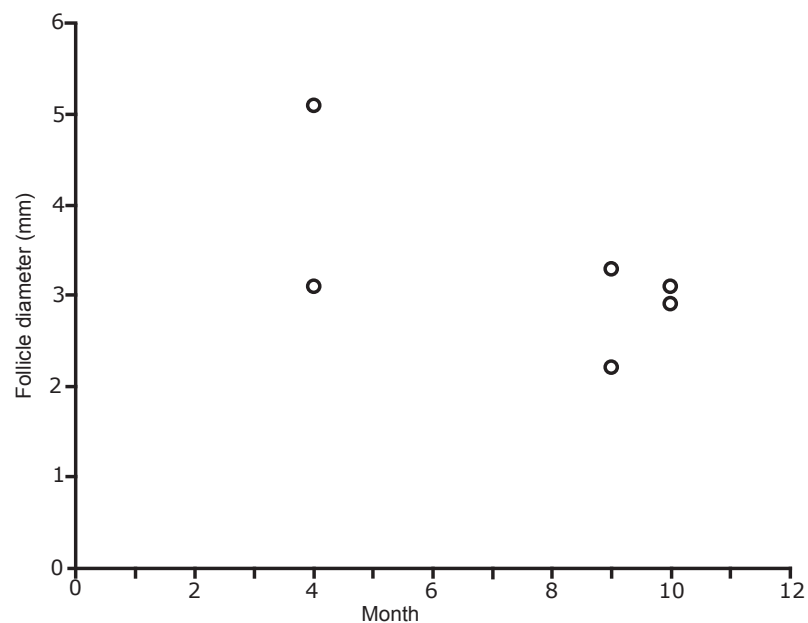

Figure 16. Monthly distribution of largest follicle size in seven Eastern Earthsnakes (Virginia valeriae valeriae) from West Virginia.
September, than could be discerned for the remaining species. Estimated annual fecundity was the trait that varied most among the five species examined in this study. The single oviparous species, the Eastern Wormsnake, produced the smallest clutch size (mean $=2.8$ ) of the species examined in this study. Among the viviparous species, mean clutch size of the Eastern Earthsnake (mean $=6.0$ ) was the smallest followed in size by that of the Northern Red-bellied Snake (mean $=12$ ) and the Northern Brownsnake (mean = 20.5). Comparatively, mean annual fecundity of each of these three species was approximately $50 \%$ that of the next largest clutch size. A significant relationship between clutch size and female body size was absent only in the Eastern Worm Snake. The Northern Brownsnake varied most among the other species in the number of traits examined, having had the longest activity season, the only bimodal seasonal incidence of captures, and the largest clutch size.

Carphophis amoenus amoenus - Adult body size varied among locations but with no apparent geographic trend (Table 1). The length of its active season in West Virginia (this study; Green and Pauley, 1987) was typical of other populations: May-September, especially during May-June in New England (Klemens, 1993), midApril-September in Pennsylvania (Hulse et al., 2001), late-March-mid-October, especially late-July-earlySeptember in Indiana (Minton, 2001), year-round, especially during May-June in North Carolina (Palmer and Braswell, 1995). Exceptionally, Virginia, with both mountains and coastal habitat, provided conditions for an extended activity season- March-December, especially May-August (Mitchell, 1994). With few exceptions, peak activity of this species, including that in West Virginia, occurred during May-June. Mating was reported during April-May in West Virginia (Green and Pauley, 1987). Oviposition in general occurred either in June, as in West Virginia, or within a few months that included June (Table 1). Likewise, a narrow range in mean clutch size of three to four eggs with a maximum of five or six eggs was laid by this species (Table 1 ). West Virginia specimens averaged 2.8 eggs per clutch and up to five eggs per clutch.

Storeria dekayi dekayi - Adult body sizes of West Virginia Northern Brownsnakes conformed to findings associated with the species range-wide, whereby males

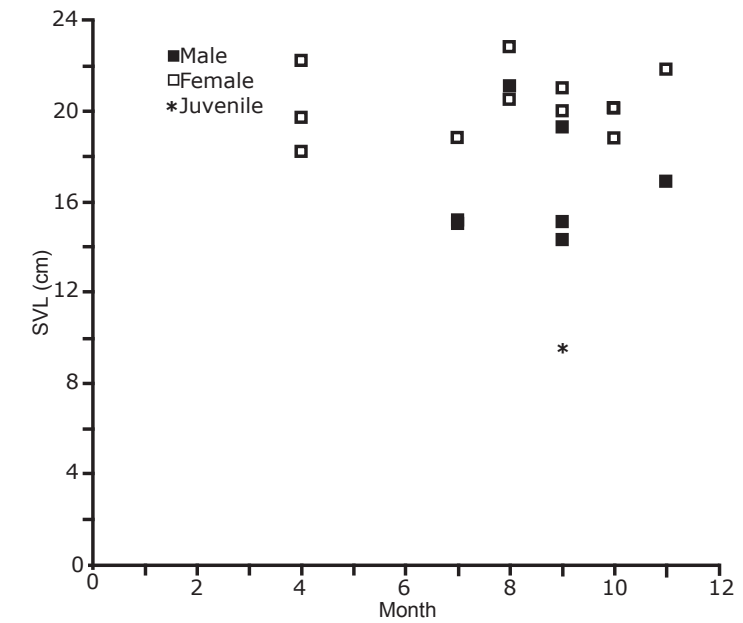

Figure 17. Monthly distribution of snout-vent lengths (SVL) of 11 male, 13 female, and one juvenile Eastern Earthsnake (Virginia valeriae valeriae) from West Virginia. 
were smaller than females and absence of a geographic trend to adult body sizes (Meshaka and Layne, 2015). The Northern Brownsnake in West Virginia was active during March-November. The long activity season of this population was in keeping with those of other locations, even among northern populations (Fogell, 2010; Meshaka and Layne, 2015). Modality of its seasonal activity could be unimodal or bimodal (Meshaka and Layne, 2015). Typical of northern populations of this species was a shorter parturition season (Meshaka and Layne, 2015) and larger clutch sizes (Fitch, 1970, 1985; Meshaka and Layne, 2015) than southern populations. Data from West Virginia conformed to these trends.

Storeria occipitomaculata occipitomaculata - Some of the smallest adults of either sex with respect to mean and minimum values were found in the South (Meshaka and Klippel, 2011). Among northern populations, some of the largest were found in Pennsylvania (Meshaka and Klippel, 2011) and in West Virginia (this study). Our data support the trend and conclusions by Meshaka and Klippel (2011) that latitude alone was not enough to explain a general trend towards larger body size in northern populations. Sexual dimorphism in SVL of our sample was similar to that of most locations, whereby male:female mean SVL was generally less than 0.90 (Meshaka, 2010). Exceptionally, M:F SVL ratio in populations in Michigan (Blanchard, 1937) and South Carolina (Semlitsch and Moran, 1984) scored 0.96. The length of its activity season in West Virginia was long, in keeping with shorter seasons among northern populations (Meshaka and Klippel, 2011). Likewise, the unimodal pattern to its capture incidence was typical of the species (Meshaka and Klippel, 2011).

Testis length and width peak during June-July in West Virginia (this study). In Pennsylvania, testis length peaked in June whereas width peaked in August (Meshaka and Klippel, 2011). Small sample size of female reproductive material but monthly distribution of follicle size did not conflict with that of Pennsylvania (Meshaka and Klippel, 2011). Presence of young-of-theyear individuals in late summer corroborates the notion of late summer parturition (Meshaka and Klippel, 2011). Mean clutch size in West Virginia Northern Red-bellied Snakes was within the range of those of other locations and it also corroborated findings of extensive variation in clutch size that was not explainable by latitude (Meshaka and Klippel, 2011).

Virginia pulchra and V. v. valeriae - Adult body size in this closely-related group was found to be larger in females across its geographic range (Table 2). Adult body size generally appeared stable in all but South Carolina locations (Table 2), where Todd et al. (2008) noted its diminutive form. Too few specimens of the Mountain Earthsnake were captured to infer patterns to its monthly pattern of capture incidence, although Ware (2008) detected individuals in West Virginia during 28 May-22 September, with a peak in observations in June. In Ware's (2008) study, males were found in the highest numbers in June, whereas females were found in equal numbers during July-August. In nearby Pennsylvania, individuals were found during late-April-mid-October, with a peak in August (Hulse et al., 2001). In Warren County, Pennsylvania, five males and 18 females, of which nine were gravid, were collected on 6 July 1963 under fine sandstone fragments on an east-facing slope (Bothner and Moore, 1964). Young were born during 7-30 September, and clutch size averaged 6.8 young (range $=5-9$ ). Ten years earlier, parturition occurred during 19 August-14 September (Richmond, 1954) when, as noted by Bothner and Moore (1964), average August air temperature was $9^{\circ} \mathrm{F}$ cooler than in their 1963 study. Also in Warren County, 17 individuals were collected on 22 July 1970 under cover on a west-facing slope (Pisani, 1971). Five clutches were produced during 18-26 August. A sixth clutch, produced by a $31.9 \mathrm{~cm}$ SVL female was produced on 12 September. She was the second largest female of the collection and produced an unusually large clutch of 14 young. Summarizing the literature, Pisani (1971), estimated an average clutch size of 5.9 young for this species.

Among West Virginia Eastern Earthsnakes, individuals were active during April-November. Green and Pauley (1987) noted activity during 1 April-16 November in West Virginia. The length of its active season fit within a north-south trend of an ever-increasing number of months in which this species was found to be active: Late March-late October in Indiana (Minton, 2001), midFebruary-mid-December in Virginia (Mitchell, 1994), end-of-February-early-November in North Carolina (Palmer and Braswell, 1995), March-November in South Carolina (Gibbons and Semlitsch, 1987). The unimodal peak in numbers of captures in our study differed from the finding of a bimodal seasonal activity period in South Carolina (Gibbons and Semlitsch, 1987).

Parturition was documented in late-summer through early-fall in West Virginia (Green and Pauley, 1987). Mean clutch size of this species ranged from four to seven, the fewest of which were produced in South Carolina (Table 2).

Summary - Patterns detected in our results allowed us to test the strength of several geographic trends in life history traits. In turn, our findings in general adhered to northern trends and identified responses suitable to inhabiting the relatively cold climate of the Allegheny province in West Virginia.

Acknowledgments - Thanks are due to the professional kindnesses of the William and Ingrid Rea Assistant Curator, Dr. José Padial-Fregenal, and Collections Manager (extraordinaire), Steve Rogers, for the loan of specimens and also to Powdermill Nature Reserve Director, Dr. John Wenzel, and Operations Manager, Cokie Lindsay, for transport of specimens. Thanks are also due to Chief Curator of the State Museum of Pennsylvania, Bradley Smith, and Executive Director of the Pennsylvania Historical and Museum Commission, Jim Vaughan, for their support of this and other projects conducted by the senior author.

\section{LITERATURE CITED}

Aldridge, R.D. 1979. Female reproductive cycles of the snakes Arizona elegans and Crotalus viridis. Herpetologica 35:256-261.

Aldridge, R.D., W.P. Flanagan, and J.T. Swarthout. 1995. Reproductive biology of the water snake Nerodia rhombifer from Veracruz, Mexico, with comparisons of tropical and temperate snakes. Herpetologica 51:182-192.

Aldridge, R.D., S.R. Goldberg, S.S. Wisniewski, A.P. Bufalino, and C.B. Dillman. 2009. The reproductive cycle and estrus in the colubrid snakes of temperate North America. Contemporary Herpetology, 2009:1-31.

Barbour, R.W. 1960. A study of the worm snake, Carphophis amoenus Say, in Kentucky. Transactions of the Kentucky Academy of Science, 21:10-16.

Blanchard, F.N. 1937. Data on the natural history of the 
red-bellied snake, Storeria occipito-maculata (Storer), in northern Michigan. Copeia, 1937:157-162.

Bothner, R.C. and T.R. Moore. 1964. A collection of Haldea valeriae pulchra from western Pennsylvania, with notes on some litters of their young. Copeia, 1964:709-710.

Brown, E.E.1992. Notes on amphibians and reptiles of the western piedmont of North Carolina. Journal of the Elisha Mitchell Scientific Society, 108:38-54.

Clark, D.R. 1970. Ecological study of the worm snake, Carphophis vermis (Kennicott). University of Kansas Publications Museum of Natural History, 19:85-194.

Fitch, H.S. 1970. Reproductive cycles in lizards and snakes. University of Kansas Publications Museum of Natural History miscellaneous Publications 52.

Fitch, H.S. 1985. Variation in clutch and litter size in new world reptiles. University of Kansas Public Museum of Natural History 76:1-76.

Fogell, D.D. 2010. Amphibians and Reptiles of Nebraska. University of Nebraska. Lincoln, Nebraska.

Gibbons, J.W. and R.D. Semlitsch. 1987. Activity patterns Pp. 396-421 In R.A. Seigel, J.T. Collins, and S.S. Novak, editors. Snakes: Ecology and Evolutionary Biology. MacMillan Company, New York, New York.

Green, N.B. and T.K. Pauley. 1987. Amphibians and Reptiles in West Virginia. University of Pittsburgh Press. Pittsburgh, Pennsylvania.

Hulse, A.C., C.J. McCoy, and E.J. Censky. 2001. Amphibians and Reptiles of Pennsylvania and the Northeast. Cornell University Press. Ithaca, New York.

Klemens, M.W. 1993. Amphibians and Reptiles of Connecticut and Adjacent Regions. State Geological and Natural History Survey of Connecticut, Bulletin No. 112.

Lamson, G.H. 1935. The reptiles of Connecticut. Bulletin of the State Geological and Natural History Survey of Connecticut, 54:1-35.

Meshaka, W.E., Jr. 2010. Seasonal activity and breeding seasons of snakes from Powdermill Nature Reserve in western Pennsylvania: The importance of sitespecific data in land management programs. Herpetological Conservation and Biology, 5:155-165.

Meshaka, W.E., Jr. and A. Klippel. 2011. Seasonal activity, reproduction, and growth of the northern redbelly snake, Storeria occipitomaculata occipitomaculata (Storer, 1839), from Pennsylvania. Journal of
Kansas Herpetology 37:16-20.

Meshaka, W.E., Jr. and J.N. Layne. 2015. The herpetology of southern Florida. Herpetological Conservation and Biology, 10(Monograph 5):1-353.

Minton, S.A., Jr. 2001. Amphibians and Reptiles of Indiana. Rev. $2^{\text {nd }}$ ed. Indiana Academy of Science. Indianapolis, Indiana.

Mitchell, J.C. 1994. The Reptiles of Virginia. Smithsonian Institution Press. Washington, DC.

Mount, R.H. 1975. The Reptiles and Amphibians of Alabama. Auburn University Agricultural Experimental Station. Auburn, AL.

Palmer, W.M. and A.L. Braswell. 1995. Reptiles of North Carolina. University of North Carolina Press. Chapel Hill, North Carolina.

Pisani, G.R. 1971. An unusually large litter of Virginia valeriae pulchra.Journal of Herpetology, 5:207-208.

Powell, R., R. Conant, and J.T. Collins. 2016. Peterson Field Guide to Reptiles and Amphibians of Eastern and Central North America. $4^{\text {th }}$ edition. Houghton Mifflin Harcourt. New York, New York.

Richmond, N.D. 1954. The ground snake, Haldea valeriae, in Pennsylvania and West Virginia with description of new subspecies. Annals of the Carnegie Museum, 33:251-260.

Saint Girons, H. 1982. Reproductive cycles of male snakes and their relationships with climate and female reproductive cycles. Herpetologica 38:5-16.

Semlitsch, R.D. and G.B. Moran. 1984. Ecology of the redbelly snake (Storeria occipitomaculata) using mesic habitats in South Carolina. American Midland Naturalist, 111:33-40.

Todd, B.T., J.D. Wilson, C.T. Winne, and J.W. Gibbons. 2008. Aspects of the ecology of the earth snakes (Virginia valeriae and $V$. striatula) in the upper coastal plain. Southeastern Naturalist, 7:349-358.

Trauth, S.E., R.L. Cox, W.E. Meshaka, Jr., B.P. Butterfield, and A. Holt. 1994. Female reproductive traits in selected Arkansas snakes. Arkansas Academy of Science, 48:196-209.

Ware, D. 2008. The natural history and distribution of the mountain earthsnake (Virginia valeriae pulchra) in West Virginia. Unpublished MS thesis. Marshall University, Huntington, West Virginia.

Wilson, J.D. and M.E. Dorcas. 2004. Aspects of the ecology of small fossorial snakes in the western piedmont of North Carolina. Southeastern Naturalist, 3:1-12. 